\title{
Physicochemical characteristics of pollen collected by Amazonian stingless bees
}

\author{
Características físico-químicas do pólen coletado por abelhas amazônicas sem ferrão
}

\section{Kemilla Sarmento Rebelo ${ }^{\mathrm{I}}$ Antônio Gilberto Ferreira ${ }^{\mathrm{II}}$ Gislene Almeida Carvalho-Zilse ${ }^{\mathrm{III}}$}

\section{ABSTRACT}

The purpose of this study was to determine the physicochemical characteristics of pollen collected by the Amazonian stingless bees Melipona seminigra and Melipona interrupta, in order to verify whether their characteristics meet the physicochemical requirements established by the Brazilian Technical Regulation for Identity and Quality of Bee Pollen. Physicochemical analyses were performed through official analytical methods. Results of pollen analyses collected by M. seminigra and $M$. interrupta were respectively as follows: moisture: 53.39 and $37.12 \%$; protein: 37.63 and 24.00\%; lipids: 10.81 and 6.47\%; ash: 4.03 and $2.74 \%$; crude fiber: 9.30 and 13.65\%; carbohydrates: 25.66 and 44.27\%; energy: 350.47 and $331.33 \mathrm{kcal} \%$; $\mathrm{pH}: 3.70$ and 3.34 ; total solids: 46.60 and $62.87 \%$, and water activity: 0.91 and 0.85 . The percentages of moisture and $\mathrm{pH}$ in pollen collected by both studied bees are not in agreement with the Technical Regulation for bee pollen. Since some characteristics, which are inherent to the Melipona pollen, were not in conform to the current Regulation, we recommend that further studies should be conducted to better characterize it, and correct the Regulation, if necessary.

Key words: Amazon, meliponinae, percent composition, bee bread.

\section{RESUMO}

Oobjetivo deste estudofoi determinar as características fisico-químicas do pólen coletado pelas abelhas amazônicas sem ferrão, Melipona seminigra e Melipona interrupta, para verificar se suas características atendem aos requisitos físico-químicos estabelecidos no Regulamento Técnico Brasileiro de Identidade e Qualidade de Pólen Apícola. As análises fisico-químicas foram realizadas através de métodos analíticos oficiais. Os resultados das análises do pólen coletado por M. seminigra e M. interrupta foram, respectivamente: umidade: 53,39 e 37,12\%; proteinas: 37,63 e
24,00\%; lipídeos: 10,81 e 6,47\%; cinzas: 4,03 e 2,74\%; fibra bruta: 9,30 e 13,65\%; carboidratos: 25,66 e 44,27\%; energia: 350,47 e 331,33kcal\%; pH: 3,70 e 3,34; sólidos totais: 46,60 e 62,87\%; e atividade de água: 0,91 e 0,85. O percentual de umidade e o $\mathrm{pH}$ do pólen coletado por ambas as abelhas estudadas está em desacordo com o Regulamento Técnico para pólen apícola. Recomendamos que sejam realizados mais estudos para melhor caracterizar este produto e atualizar o Regulamento vigente, se necessário, pois algumas características que não atendem ao Regulamento são inerentes ao pólen de Melipona.

Palavras-chave: Amazônia, meliponíneos, composição centesimal, samburá.

\section{INTRODUCTION}

Bees collect pollen from plants groups which are specific for each species (KERR et al., 2001). They transport it to the hive, compressed with nectar in the pollen baskets of their third pair of rear legs (VIT \& SANTIAGO, 2008). After some time of storage, the stingless bees regurgitate glandular substances into a pollen pot, for fermentation and for their own consumption (KERR et al., 1996). Pollen has also been occasionally consumed by humans, as a supplement food, in industrialized capsules (KROYER \& HEGEDUS, 2001), either added to honey or pure and dehydrated.

Although honey production is significant, there is a growing interest in bee pollen mainly due to

\footnotetext{
Instituto de Saúde e Biotecnologia, Universidade Federal do Amazonas (UFAM), 69460-000, Coari, AM, Brasil. E-mail: kemillasr@yahoo.com.br. Corresponding author.

IDepartamento de Química, Universidade Federal de São Carlos (UFSCar), São Carlos, SP, Brasil.

III Grupo de Pesquisas em Abelhas, Coordenação de Biodiversidade, Instituto Nacional de Pesquisas da Amazônia (INPA), Manaus, AM, Brasil.
} 
stimuli to consume natural products for a healthy diet or therapeutic effects (SALOMÉ \& SALOMÉ, 1998; PETERSEN et al., 2011).

Because of its floral origin, bee pollen may have a variable composition depending on the region or season (MODRO et al., 2007). Its composition includes proteins, lipids, fibers (MARCHINI et al., 2006), minerals (FUNARI et al., 2003), vitamins C and $E$ and $\beta$-carotene (ALMEIDA-MURADIAN et al., 2005; OLIVEIRA et al., 2009), free amino acids (PARAMAS et al., 2006), sugars (QIAN et al., 2008), unsaturated fatty acids (FEAS et al., 2012), and phenolic compounds (MARGHITAS et al., 2009).

The main bee species created in Brazil is Apis mellifera Linnaeus, 1758, from Europe and Africa. The most worldwide studied type of pollen is that collected by the species $\boldsymbol{A}$. mellifera, and little is known about the chemical composition of pollen collected by the stingless bees. In this sense, knowing its components is important to characterize the products obtained from different regions, climates, and bee species, to have a better quality control, and encourage the creation of stingless bees for commercial extraction of their products.

The first purpose of the present study was to analyze the physicochemical characteristics of pollen collected by the Amazonian stingless bees $\boldsymbol{M}$. seminigra and M. interrupta to verify whether there are differences between them. An additional purpose was to know whether their characteristics meet the physicochemical requirements as established in the Technical Regulation for Identity and Quality of Bee Pollen (BRASIL, 2001), which is based on pollen collected by the stinging bee $A$. mellifera .

\section{MATERIALS AND METHODS}

The pollen samples were collected in colonies of stingless bees of the species M. seminigra and M. interrupta, in March 2010. Colonies belong to the Meliponary of the Group for Research on Bees, which is located in the Instituto Nacional de Pesquisas da Amazônia in Manaus, AM, Brazil.

Closed cerumen pots with pollen were withdrawn from the hives of both species and were later unoperculated. Part of the fresh pollen was separated for analysis of water activity, $\mathrm{pH}$, total solids, and moisture. The other part of the pollen was lyophilized $(8 \mathrm{~h})$ in a Terroni $^{\circledR}$ (LS-3000) lyophilizer, macerated, stored in polyethylene vials with cap, and kept under refrigeration $\left(4^{\circ} \mathrm{C}\right)$ on a dry basis until analysis. All analyzes were performed in triplicate.
Moisture content was evaluated by desiccation in a vacuum oven $\left(70^{\circ} \mathrm{C}\right)$ according to the 926.12 AOAC (1996) method, until constant weight was reached. The protein percentage was determined by the Kjeldahl method (AOAC, 991.20; 1996), by which the total nitrogen content of the sample was calculated.

Lipids were determined using the method of BLIGH \& DYER (1959), by which the lipids were extracted with a cold mixture (chloroform, methanol, and water) of solvents. The ash content was determined by incineration in a muffle $\left(550^{\circ} \mathrm{C}\right)$, according to the 900.02 method (AOAC, 1996). The percentage of crude fiber was determined by the method recommended by the AOAC (1996).

The percentage content of available carbohydrates was calculated by the difference between 100 and the sum of water, protein, lipid, crude fiber, and ash percentages. The energy value was calculated from the content of protein, carbohydrates (subtracting the crude fiber content) and lipids, according to the Atwater (4.0, 4.0, and 9.0 kcal g-1, respectively) factors (MERRILL \& WATT, 1973).

The $\mathrm{pH}$ values were determined by using a previously calibrated digital $\mathrm{pH}$ meter (model pHS3B; Labmeter ${ }^{\mathbb{B}}$ ), according to the analytical rules of the IAL (INSTITUTO ADOLFO LUTZ, 2008). The total solids were quantified by gravimetry, through the difference between the total weight of the fresh sample and its moisture content (CECCHI, 2003). Water activity was determined (mean temperature: $25.2^{\circ} \mathrm{C}$ ) in a specific equipment (Pawkit; Decagon ${ }^{\circledR}$ ).

The results were statistically analyzed by calculating and comparing the values for mean, standard deviation, and confidence interval of three replicates $(\mathrm{P}<0.05)$ in the statistical $\left(\right.$ Minitab $^{\circledR}, \mathrm{v}$. 17.1, 2013) program.

\section{RESULTS AND DISCUSSION}

The physicochemical characteristics of the pollen collected by $M$. seminigra and M. interrupta are shown in table 1 .

\section{Moisture}

The pollen samples of both bees (Table 1) showed not to comply with the Technical Regulation for bee pollen, which recommends $30 \%$ as the maximum value for moisture. SOUZA et al. (2004), lyophilized (8h) and determined the mean moisture of $36.9 \%$, (range: $22.3-49.2 \%$ ) in pollen samples collected by stingless bees of the genus Melipona, in the period of Nov-Dec 2002, in the state of Amazonas. In the present study, the mean values for 
Table 1 - Physicochemical characteristics of pollen samples collected by the bees Melipona seminigra and Melipona interrupta from the Meliponary GPA/INPA, Manaus, AM, Brazil.

\begin{tabular}{|c|c|c|}
\hline Physicochemical characteristics & Pollen collected by $\boldsymbol{M}$. seminigra & Pollen collected by $\boldsymbol{M}$. interrupta \\
\hline Moisture (\%) & $53.39^{\mathrm{a}} \pm 0.50$ & $37.12^{\mathrm{b}} \pm 0.60$ \\
\hline Proteins $(\%)^{*}$ & $37.63^{\mathrm{a}} \pm 1.71$ & $24.00^{\mathrm{b}} \pm 0.01$ \\
\hline Lipids $(\%)^{*}$ & $10.81^{\mathrm{a}} \pm 0.92$ & $6.47^{\mathrm{b}} \pm 0.15$ \\
\hline Ashes $(\%)^{*}$ & $4.03^{\mathrm{a}} \pm 0.46$ & $2.74^{\mathrm{b}} \pm 0.02$ \\
\hline Crude fibers $(\%)^{*}$ & $9.30^{\mathrm{a}} \pm 0.37$ & $13.65^{\mathrm{b}} \pm 1.57$ \\
\hline Carbohydrates $(\%)^{*}$ & $25.66^{\mathrm{a}} \pm 3.38$ & $44.27^{\mathrm{b}} \pm 1.55$ \\
\hline Energy values $(\mathrm{kcal})^{*}$ & $350.47^{\mathrm{a}} \pm 2.30$ & $331.33^{\mathrm{a}} \pm 5.76$ \\
\hline $\mathrm{pH}$ values & $3.70^{\mathrm{a}} \pm 0.01$ & $3.34^{\mathrm{b}} \pm 0.02$ \\
\hline Total solids (\%) & $46.60^{\mathrm{a}} \pm 0.50$ & $62.87^{\mathrm{b}} \pm 0.60$ \\
\hline Water activity & $0.91^{\mathrm{a}} \pm 0.01$ & $0.85^{\mathrm{b}} \pm 0.00$ \\
\hline
\end{tabular}

Values established in the Technical Regulation for Identity and Quality of Bee Pollen (Brasil, 2001): Moisture: max. 30\%; Protein: min. 8\%; Lipids: min. 1.8\%; Ashes: max. 4\%; Crude fiber: $\min .2 \%$; Total sugars: $14.5-55.0 \%$; pH: 4.0-6.0.

Mean \pm standard deviation $(\mathrm{n}=3)$.

${ }^{*} \mathrm{~m} / \mathrm{m}$; dry weight basis.

Mean values followed by the same letter (in the line) are not different by the confidence interval as analyzed by the Student's $t$ test ( $\mathrm{P}<0.05$ ).

pollen collected by $\boldsymbol{M}$. interrupta were similar to those determined in the literature.

MARCHINI et al. (2006) investigated pollen samples collected by honeybees $A$. mellifera, in the region of Piracicaba, SP, Brazil, and reported a mean value of $33.2 \%$ in Jan $/ 2000$, the period when more rain occurred in the studied area. These authors stated that bee pollen is an extremely hygroscopic material, which can be affected by environmental conditions. For this reason, it is likely that the samples used in the present study showed a high moisture content, as they were collected in a period (March) when the air relative humidity is usually high and the atmospheric precipitations are intense in the Amazon region (ANDREAE et al., 2002). The high moisture content of meliponine-collected pollen can favor fermentation processes, which are characteristic of stingless bee pollen.

BASTOS et al. (2003) analyzed the composition and quality of pollen collected by $\boldsymbol{A}$. mellifera, which is sold in some cities in the states of São Paulo and Minas Gerais, and reported a percentage moisture of $19.3 \%$. However, these authors used a volumetric method based on aquametry with the "Karl Fischer" reagent.

Protein

Bee pollen usually has a high protein content (MODRO et al., 2007). Pollen samples analyzed in this study presented a high content of this nutrient (Table 1), when compared to samples studied by other researchers.
SOUZA et al. (2004), VIT \& SANTIAGO (2008), and MODRO et al. (2009) obtained, respectively, the protein percentage values of 19.50 , 24.17-52.56, and $26.20 \%$ in bee pollen samples, using factor 6.25 for conversion of nitrogen content.

The standard factor to convert nitrogen into protein content is not defined in the current regulation (BRASIL, 2001), and this lack should be considered regarding pollen protein analysis by the Micro Kjeldahl method. Authors such as BELL et al. (1983) claim that factor 6.25 may overestimate the protein content, and recommend the use of factor 5.6 to convert nitrogen into protein content. These authors reported that about $30 \%$ of nitrogen content determined in pollen samples may be of non-protein origin, because a large part of it comes from free amino acids.

MCCAUGHEY et al. (1980), and LOPER $\&$ COHEN (1987) pointed out that the nutritional quality of protein-rich pollen is reduced if the amounts of essential amino acids is low. Their studies suggested that accuracy by amino acid composition is higher than by protein content in defining the nutritional value of pollen.

Lipids

All samples met the values recommended in this Regulation (minimum 1.8\%). The values found for lipid content of stingless bee-collected pollen are relatively high (Table 1) when compared to those of SOUZA et al. (2004), who studied the same species. These authors obtained the mean value of $4.0 \%$, similar 
to the value found by MARCHINI et al. (2006), who analyzed pollen of bees of the genus Apis (3.6\%). In these two studies, the Soxhlet method was used.

In the present study, we used the BlighDyer method to analyze the lipid levels of bee pollen, and our values are closer to those reported by BASTOS et al. (2003) who used the same method and found levels in the range of $6.1-14.0 \%$.

BRUM et al. (2009) stated that the good yield in the analyses of total lipids, using the BLIGH \& DYER (1959) method, can be explained by the broad polarity range of the solvent mixture, and the solvent polarities are higher than those used in the SOXHLET method (1879). Therefore, the extraction of both polar and non-polar lipids is efficient.

According to CAMPOS et al. (2008), results of gas chromatography analysis revealed that lipids extracted from pollen consisted mainly of fatty acids, such as linolenic, palmitic, linoleic and oleic acids, and unsaturated fatty acids, which were about $70 \%$ of total pollen lipids (SERRA-BONVEHI \& ESCOLA-JORDA, 1997; SZCSZENA \& RYBAKCHMIELEWSKA, 1998).

\section{Ashes}

All samples met the recommendation of the Technical Regulation for bee pollen (maximum 4\%). The ash percentage reported in pollen samples analyzed in the present study (Table 1), is close to that reported in other studies. SOUZA et al. (2004) calculated the mean value of $2.1 \%$ for ash in the meliponine bee pollen in the state of Amazonas. MODRO et al. (2009) also found $2.1 \%$, but in pollen collected by $A$. mellifera in a region of the Atlantic forest in the state of Minas Gerais. In turn, CARPES et al. (2009) reported a mean value of $2.9 \%$ in pollen collected by $A$. mellifera in the Southern region of Brazil.

\section{Crude fibers}

The percentage of crude fiber of pollen collected by the two stingless bee species (Table 1) was relatively high when compared to the values (mean: 3.4\%; range 2,2-4,9\%) reported by CARPES et al. (2009) in pollen collected by $\boldsymbol{A}$. mellifera from the Southern region of Brazil. However, the values reported for crude fiber in the present study were closer to those found by BELL et al. (1983) in bee pollen from varieties of eucalyptus in Australia (6.9$15.6 \%$ ). The differences between the fiber content in the pollen collected by meliponines and $A$. mellifera may be due to the different types of flowers, which are visited by these bees and used by them as a pollen source. The samples analyzed comply with the
Regulation (minimum 2\%).

\section{Carbohydrates}

Carbohydrate was the macronutrient with the greatest amount in the pollen samples analyzed in this study (Table 1). The value reported in this study for carbohydrates in pollen samples was similar to that reported by HUMAN \& NICOLSON (2006) in fresh pollen from South Africa (34.7\%), and SOUZA et al. (2004) calculated a mean percentage of $37.5 \%$ for glycides in meliponine-collected pollen. The Technical Regulation for bee pollen determines that the total sugar content can vary in the range $14.5-55.0 \%$ on a dry weight basis. Thus, the pollen collected by $\boldsymbol{M}$. interrupta meets the recommended values.

\section{Energy value}

The simplified calculation of energy value for a food depends on the quantities of macronutrients present in it. The pollen samples analyzed in the present study are attributed to high caloric values due to their high lipid content.

In the present study, stingless beecollected pollen samples were analyzed for energy and our values (Table 1) were higher than those reported by SOUZA et al. (2004), who also studied the same gender of bees in the state of Amazonas. These samples presented a mean value of $264.4 \mathrm{kcal}$ per $100 \mathrm{~g}$, mainly due to the lipid content, which was lower than that reported in the present study.

According to VINCENZI (2004), the daily intake of pollen should not exceed $15 \mathrm{~g}$. The recommendation for pollen consumption is $10-15 \mathrm{~g}$ day $^{-1}$ for adults, $4-6 \mathrm{~g} \mathrm{~d}^{-1}$ for children aged 3-5 years, and $8-13 \mathrm{~g} \mathrm{~d}^{-1}$ for children aged 6-12 years. Therefore, pollen intake provides a maximum of $52 \mathrm{kcal} \mathrm{d}^{-1}$.

$\mathrm{pH}$

The $\mathrm{pH}$ values of pollen aqueous solutions (Table 1) were lower than those determined by MARCHINI et al. (2006), who studied pollen samples collected by the bee species $\boldsymbol{A}$. mellifera and obtained the mean value of 5.1 (range: 4.8-5.3) in the period from Mar/99 to Mar/00. BASTOS et al. (2003) found $\mathrm{pH}$ values closer to those determined in the present study (range 3.7-5.5).

The low $\mathrm{pH}$ values obtained in the present study do not meet the requirements established in the Technical Regulation for bee pollen. However, this Regulation is based on bee pollen from colonies of the honeybee $\boldsymbol{A}$. mellifera, whose pollen is collected in the entrance to the hives. The condition is different 
from that for stingless bee pollen, which is stored inside the hives and undergoes fermentation processes that may influence the $\mathrm{pH}$ value for this product.

Total solids

MARCHINI et al. (2006) and MODRO et al. (2007) reported, respectively, 76.3 and $72.0 \%$ of total solids in pollen collected by $\boldsymbol{A}$. mellifera. These values were higher than those reported in stingless bee collected pollen, which was used in the present study (Table 1).

The total solid content is directly related to the moisture content of the samples. The higher the total solid content, the lower the time required for dehydration. The pollen sample collected by $\boldsymbol{M}$. seminigra presented $46.60 \%$ of total solids due to its higher moisture content (53.39\%). In turn, pollen sample collected by M. interrupta showed $62.87 \%$ of total solids, due to its smaller moisture content $(37.12 \%)$. Therefore, this type of pollen requires less time for dehydration, and this fact can facilitate processing for commercialization purposes.

\section{Water activity (wa)}

Various microorganisms that deteriorate food cannot develop in products with aw values lower than 0.90 (CORREIA-OLIVEIRA et al., 2008). The highest value for wa (0.6) reported by BASTOS et al. (2003) was observed in dehydrated bee pollen sold in some cities in the states of São Paulo and Minas Gerais.

Water activity determined in fresh pollen samples analyzed in the present study showed high values (Table 1). Therefore, we emphasize that pollen for commercialization must be conveniently dehydrated, since food with low values for wa are better preserved.

\section{CONCLUSION}

Most physicochemical characteristics of pollen samples collected by stingless bee of the species $M$. seminigra were significantly different from those of the species M. interrupta. Only the energy value did not show significantly difference between these species.

The values for moisture and $\mathrm{pH}$ of samples collected by both study bees, did not meet the recommendations of the Brazilian Technical Regulation, which establishes the values for identity and quality of bee pollen. Therefore, we recommend that further studies should be conducted to better characterize this product, and the specific Technical
Regulation need to be updated, if necessary, because some characteristics that do not met the Regulation appear to be inherent to the Melipona pollen.

\section{ACKNOWLEDGEMENTS}

To the Conselho Nacional de Desenvolvimento Científico e Tecnológico (CNPq) for the scholarship granted to the first author. To the Fundação de Amparo à Pesquisa do Estado do Amazonas (FAPEAM) for the financial support.

\section{REFERENCES}

ALMEIDA-MURADIAN, L.B. et al. Chemical composition and botanical evaluation of dried bee pollen pellets. Journal of Food Composition and Analysis, v.18, p.105-111, 2005. doi: 10.1016/j. jfca.2003.10.008

ANDREAE, M.O. et al. Biogeochemical cycling of carbon, water, energy, trace gases, and aerosols in Amazonia: The LBAEUSTACH experiments. Journal of Geophysical Research, v.107, p.33/133/25, 2002. doi: 10.1029/2001JD000524

AOAC (ASSOCIATION OF OFFICIAL ANALYTICAL CHEMISTS). Official methods of analysis of the Association of Official Analytical Chemists. 16 ed. Arlington, 1996. 937p.

BASTOS, D.H. et al. Composição e qualidade de pólen apícola comercializado em algumas cidades nos estados de São Paulo e Minas Gerais-Brasil. Revista do Instituto Adolfo Lutz, v.62, p.239-244, 2003.

BELL, R.R. et al. Composition and protein quality of honeybeecollected pollen of Eucalyptus marginata and Eucalyptus calophylla. Journal of Nutrition, v.113, p.2489-2484, 1983.

BLIGH, E.G.; DYER, W.J. A rapid method of total lipid extraction and purification. Canadian Journal of Biochemistry and Physiology, v.37, p.911-917, 1959.

BRASIL. Instrução Normativa n. 3, de 19 de janeiro de 2001. Regulamentos técnicos de identidade e qualidade de apitoxina, cera de abelha, geléia real liofilizada, pólen apícola, própolis e extrato de própolis. Diário Oficial da União, Brasília, DF, 23 jan. 2001, Seção 1, p.18.

BRUM, A.A.S. et al. Métodos de extração e qualidade da fração lipídica. Química Nova, v.32, p.849-854, 2009. doi: 10.1590/ s0100-40422009000400005.

CAMPOS, M.G.R. et al. Pollen composition and standardization of analytical methods. Journal of Apicultural Research, v.47, p.156-163, 2008.

CARPES, S.T. et al. Chemical composition and free radical scavenging activity of Apis mellifera bee pollen from Southern Brazil. Brazilian Journal of Food Technology, v.12, p.220-229, 2009. doi: 10.4260/BJFT2009800900016.

CECCHI, H.M. Fundamentos teóricos e práticos em análise de alimentos. 2.ed. São Paulo: UNICAMP, 2003. 207p.

CORREIA-OLIVEIRA, M.E. et al. Atividade de água (aw) em amostras de pólen apícola desidratado e mel do estado de Sergipe. Revista da Fapese, v.4, p.27-36, 2008. 
FEAS, X. et al. Organic bee pollen: botanical origin, nutritional value, bioactive compounds, antioxidant activity and microbiological quality. Molecules, v.17, p.8359-8377, 2012. doi: 10.3390/molecules17078359.

FUNARI, S.R.C. et al. Composições bromatológica e mineral do pólen coletado por abelhas africanizadas (Apis mellifera L.) em Botucatu, Estado de São Paulo, Brasil. Archivos Latinoamericanos de Producción Animal, v.11, n.2, p.88-93, 2003.

HUMAN, H.; NICOLSON, S.W. Nutritional content of fresh, bee-collected and stored pollen of Aloe greatheadii var. davyana (Asphodelaceae). Phytochemistry, v.67, p.1486-1492, 2006. doi: 10.1016/j.phytochem.2006.05.023.

IAL (INSTITUTO ADOLFO LUTZ). Normas analíticas do Instituto Adolfo Lutz: métodos físico-químicos para análise de alimentos. 4.ed. 1.ed dig. São Paulo, 2008. 1020p.

KERR, W.E. et al. Abelha uruçu: biologia, manejo e conservação. Belo Horizonte: Fundação Acangaú, 1996. 144p.

KERR, W.E. et al. Aspectos poucos mencionados da biodiversidade amazônica. Brasília: MCT, 2001. 22p.

KROYER, G.; HEGEDUS, N. Evaluation of bioactive properties of pollen extracts as functional dietary food supplement. Innovative Food Science \& Emerging Technologies, v.2, p.171-174. 2001. doi: 10.1016/S1466-8564(01)00039-X.

LOPER, G.M.; COHEN, A.C. Amino acid content of dandelion pollen: a honey bee (Hymenoptera: Apidae) nutritional evaluation. Journal of Economic Entomology, v.80, p.14-17, 1987. doi: 10.1093/jee/80.1.14.

MARCHINI, L.C. et al. Composição físico-química de amostras de pólen coletado por abelhas africanizadas Apis mellifera (Hymenoptera: Apidae) em Piracicaba, Estado de São Paulo. Ciência Rural, v.36, p.949-953, 2006. doi: 10.1590/S010384782006000300034 .

MARGHITAS, L.A. et al. In vitro antioxidant capacity of honeybee-collected pollen of selected floral origin harvested from Romania. Food Chemistry, v.115, p.878-883, 2009. doi: 10.1016/j.foodchem.2009.01.014.

MCCAUGHEY, W.F. et al. Amino acids and protein adequacy for honey bees of pollens from desert plants and other floral sources. Apidologie, v.11, p.75-86, 1980. doi: 10.1051/apido:19800109.

MERRILL, A.L.; WATT, B.K. Energy value of foods: basis and derivation. United States: Agriculture Handbook, 1973. 105p.

MODRO, A.F.H. et al. Analysis of bee pollen based on color, physicochemical composition and botanical source. Anais da Academia Brasileira de Ciências, v.81, p.281-285, 2009. doi: 10.1590/S0001-37652009000200014.
MODRO, A.F.H. et al. Composição e qualidade de pólen apícola coletado em Minas Gerais. Pesquisa Agropecuária Brasileira, v.42, p.1057-1065, 2007. doi: 10.1590/S0100204X2007000800001

OLIVEIRA, K.C.L.S. et al. Relationship between botanical origin and antioxidants vitamins of bee-collected pollen. Química Nova, v.32, p.1-4, 2009. doi: 10.1590/S010040422009000500003 .

PARAMAS, A.M.G. et al. HPLC-fluorimetric method for analysis of amino acids in products of the hive (honey and beepollen). Food Chemistry, v.95, p.148-156, 2006. doi: 10.1016/j. foodchem.2005.02.008.

PETERSEN, J. et al. Comercialização do pólen apícola em 11 países da América Latina. In: SEMINÁRIO BRASILEIRO DE PRÓPOLIS E PÓLEN, 2011, Ilhéus, BA. Anais... Cruz das Almas: Magistra, 2011. p.14-16. CD.

QIAN, W.L. et al. Analysis of sugars in bee pollen and própolis by ligand Exchange chromatography in combination with pulsed amperometric detection and mass spectrometry. Journal of Food Composition and Analysis, v.21, p.78-83, 2008. doi: 10.1016/j.jfca.2007.

SALOMÉ, J.A.; SALOMÉ, L.G. Manual prático de produção de pólen apícola. Santa Catarina: Confederação Brasileira de Apicultura, 1998. 55p.

SERRA-BONVEHÍ, J.; ESCOLÁ JORDÁ, R. Nutrient composition and microbiological quality of honeybee-collected pollen in Spain. Journal of Agricultural and Food Chemistry, v.45, p.725-732, 1997. doi: 10.1021/jf960265q.

SOUZA, R.C.S. et al. Valor nutricional do mel e pólen de abelhas sem ferrão da região amazônica. Acta Amazonica, v.34, p.333336, 2004. doi: 10.1590/S00449672004000200021.

SOXHLET, F. Die Gewichtsanalytisch e bestimmung des milchfettes. Polytechnisches Journal, v.232, p.461-465, 1879.

SZCSZENA, T.; RYBAK-CHMIELEWSKA, H. Some properties of honey bee collected pollen. In: POLNISCH-DEUTSCHES SYMPOSIUM SALUS Apis Mellifera, new demands for honey bee breeding in the 21 st century. Pszczelnicze Zeszyty Naukowe, v.42, p.79-80, 1998.

VINCENZI, V.M. O pólen apícola como elemento potencializador dos efeitos advindos da atividade física orientada em idosas. Florianópolis: Programa de Pós-Graduação em Agro ecossistemas, Universidade Federal de Santa Catarina, 2004. 105 p.

VIT, P.; SANTIAGO, B. Composición química de polen apícola fresco recolectado em el páramo de Misintá de los andes venezolanos. Archivos Latinoamericanos de Nutricion, v.58, p.411-415, 2008. 